Station is on an international basis. "No words," says Verdoorn, "can describe the inspiration, as well as the scientific results, for which the Naples Station may be given credit."

To afford comparable facilities in suitable areas in the tropics Verdoorn makes a plea for the establish-. ment of what he describes as "Visitors' Research Stations". Many will sympathize with him in this aim. The present method whereby visitors make use of facilities already existing, such as the laboratories of botanic gardens, departments of agriculture, etc., has its disadvantages. It is true that, by his personal influence, Treub as director of the Buitenzorg Botanic Gardens in Java and later at Tjibotas created what was in fact an informal, international, biological station, and men of science were attracted to it from all parts of the world. $\mathrm{He}$ organised a small, well-equipped laboratory for visitors, and provided adequate but inexpensive living facilities. Verdoorn would, however, prefer to have such facilities on a different footing. Briefly, his model would operate along the following lines. The Visitors' Station would not be informal and dependent; but a more or less independent unit, associated with the existing agricultural or biological institutions. It would consist of a large modern laboratory, equipped for simple research in all branches of biology, physiology, chemistry, etc. It would be provided with a small library of general reference works, for example, literature on local floras, maps, etc., periodicals being consulted in the large libraries of the adjacent institutions. There would be a small 'social building' with a theatre for films, lectures, etc., and, not least important, a modern dormitory and restaurant and a medical annexe, each with its permanent staff.

The laboratory would have a small permanent staff, consisting of a director-"an organiser with international experience and idealism, willing to sacrifice a good part of his own opportunities for research in order to aid and assist others"- -and a small number of resident specialists well versed in the local flora, fauna, etc., and therefore capable of directing visitors to the materials which they might require in their work.

The aims of such a station would be, broadly speaking, to promote scientific research in the tropics and to develop interest in biological science at all levels of specialization against the tropical background. As to why these things should be done, Verdoorn gives several reasons. Access by biologists to tropical materials, and personal experience of tropical conditions, are of themselves of great importance. But Verdoorn gives another reason of great practical importance at the present time, and possibly for decades to come. "Except in times of worldwide economic depression, it is difficult to get even fair numbers of first-class scientists to do research and experiment station work for the majority of the tropical countries. It has always been so and will remain so in most countries, whatever progress is made in travel, medicine, refrigeration, and local education. For the development and reconstruction of the larger tropical areas a great number of scientists are needed. They must be good scientists, not men who come merely because they cannot succeed elsewhere." This is absolutely correct and sound. No one with recent experience of agriculture, and biological science generally, in the tropics, whether of the Old World or of the New, will challenge this statement. There have been too few good biologists in the tropics in the past : the personnel situation is still more aggravated at the present time while the problems have gained in magnitude.

On the location of the visitors' research stations, Verdoorn is explicit: they will be developed in proximity to existing institutions, for example, at Buitenzorg, Calcutta, Peradeniya, Manila, etc. There should, of course, be a close and sympathetic under. standing between the visitors' station and the existing institutions.

Lastly, while the general argument has been developed in terms of the biological sciences, the field of work could be extended to all scientific subjects where field-work is important. The method of procedure for the development and financing of such stations has yet to be worked out. Whatever the system eventually adopted may be, biologists have reason to be grateful to Dr. Verdoorn for his timely emphasis of the fact that facilities for tropical study should be provided on an international basis as soon as possible in the general interest.

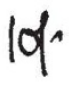

\section{MEASUREMENT OF VISCOSITY}

A MEETING of the British Rheologists' Club was held on Jyne 15 at the National Physical Laboratory, Tedffigton, by courtesy of the director, when Dr. Guy Barr spoke on recent developments in viscometry 1 theluding the calibration and design of stafadar 8 viscometers.

A tor giving a survey of early ideas on viscosity leading to Maxwell's definition of dynamic viscosity, Dr. Barr stressed the importance of kinematic viscosity, which came into importance later because of its application in hydraulics and especially in aerodynamics. Until 1913, no name was attached to the unit of viscosity ; Deeley and Parr then suggested the word 'poise' (from Poiseuille) for $\eta$, the unit of dynamic viscosity; and later, in 1928, Jakob proposed the word 'stoke' (from Stokes) for $v$, the unit of kinematic viscosity ; $\nu=\eta / \sigma$ where $\sigma$ is the density of the liquid. These names and their derivations, namely, centipoise (cp.) and centistoke, have been universally adopted. The poise has the dimensions $M L^{-1} T^{-1}$, and is correctly expressed as grams/cm./sec., whereas the stoke has the dimensions $L^{2} T^{-1}$, that of a diffusion of momentum.

Dr. Barr pointed out that the Ostwald, and U-type viscometers in general, are subject to small errors if not placed strictly vertical, and modifications of their design to minimize the error have been made by Gruneisen, Fenske, Ubbelohde, and others; these modifications are much in use with petroleum pro. ducts. Fenske places the reservoirs one above the other and Ubbelohde in his suspended level viscometer does not require any particular quantity of liquid. Small discrepancies in results obtained with carefully calibrated standard viscometers by observers in different laboratories (joint meeting of Institute of Petroleum and British Rheologists' Club, J. Inst. Pet., 31, 260; 1945) cannot be attributed to gravity variations, observational errors, or lack of temperature control, etc., but appear to be due to differences of surface tension in the standard liquids used for calibration. With water and sugar solutions, the surface tensions and contact angles are considerably higher than with the petroleum oil standard calibrating liquids. Dr. Barr described experiments illustrating the effect of surface tension on the flow 
of liquids in viscometers, and exhibited viscometers designed to eliminate the surface tension difficulty.

On the subject of the measurement of viscosity of non-Newtonian liquids, Dr. K. Weissenberg mentioned the method of making the liquid system vibrate and observing the wave motion. The meeting discussed the use of the falling sphere method; Dr. E. Mardles pointed out that the rate of fall of a sphere through paints and greases varies considerably with depth, and often the sphere remains suspended, a finding confirmed by Dr. Barr, who with an unusual sample of tar and using X-ray photography found that the ball remained practically suspended before reaching the bottom. Dr. Mardles has obtained more promising results by using a thin plate drawn through the system, the rate of movement being nearly constant through the bulk. By varying the weight attached to the fine thread over a light pulley pulling the plate, it is possible to determine the yield value (see Nature, August 10, p. 199).

Those present visited departments where investigations of a rheological character were in progress; these included the silting of harbours, the slow creep of metals, the ventilation of buildings, plastics, use of strain gauges, etc.

\section{$|2|$ \\ UTILIZATION OF AFRICAN FOREST WOODS}

$\mathrm{W}$ AR production forms the main theme of the annual reppet of some of the African forest services-thos for nds for timber and wild rubber proguction, th latter due to the disappearance of the Malatin supplies. In the report for 1943 from Nilof (Govt. Printers, Lagos, 1944) it is stated that military demands for timber revived, while the projected relaying of the railway line between Jebba and Minna required over a period of three years 300,000 sleepers. It was hoped to supply a high proportion of these from the Kurmis of the northern provinces, from Khaya senegalensis and grandifoliola. Trouble was experienced from warping and cracking due to an exceptionally severe harmattan; an exacting specification impossible for pit-sawyers to fulfil and other difficulties were experieneed. These resulted in a high percentage of rejects, so the work of supplying is to be transferred to the southern provinces, although this involves long haulages by rail. Besides this railway contract, of which a portion was cut, $333,358 \mathrm{cu}$. ft. were produced for military use ; $1,455,730 \mathrm{cu}$. ft. for local consumption ; $40,924 \mathrm{cu}$. ft. from the mines, and $2,038,592 \mathrm{cu}$. ft. by logs and timber cut for export. This latter went to the United Kingdom, United States, South Africa, other parts of West Africa and French West Africa. One notable result of this increased war demand for timber, especially sawn timber required by the military, is the substantial and growing local demand by the African for this last type of material, which should, in the future, result in far better housing conditions for the population.

In the report for 1943-44 from the Gold Coast (Govt. Printing Department, Accra, 1944) timber and rubber production appear to have proved the chief preoccupations of the Department. Apart from the pit-sawn timber used locally, the pit-sawn timber supplies handled by the Department through its numerous subcontractors totalled 1,060,000 $\mathrm{cu}$. ft. This was supplied to the British Services, United States Army, Government Departments, etc. 133,000 pit-sawn sleepers required for an extension of the Gold Coast Railway and demanded at short notice were included in the above. One outcome of the military demand was the making of furniture in the Colony, a woodworkers' company having been started in Accra. Here again this may lead to the adoption of better types of furniture in the houses of the Africans in the future. In the Gold Coast, as in India and other parts of the Empire, the demand for tool handles was met by local production, and cutlass handles, and handles for felling axes, pick axes, shovels, hoes, rakes and all kinds of hammers were prepared from local woods; as also shingles for roofing.

The annual report for 1944 for Uganda (Government Printing Department, Uganda, 1945) says that the demand for timber for operational use by the military became more pressing and everything possible was done to increase output by opening up new areas and arranging for the circulation and extension of sawmills. The nine firms working exclusive licences operated twelve mills and produced 32,873 tons of $50 \mathrm{cu}$. ft. of sawn timber each. plus 746 tons of export logs. Eleven other firms with twelve mills turned out 7,541 tons of sawn timber, while pit-sawyers produced 3,835 tons. This timber came from the crown lands, crown forests and private forest (about one sixth only). 79 per cent of the total went to the military, $8 \frac{1}{2}$ per cent to the civil governments, and the balance to the public. Exports were 749 tons of logs and 39,148 tons of sawn timber, including 126,395 sleepers. The report gives interesting information on the wild rubber collection, which has absorbed a proportion of the staff of all the Departments. "The Wild Rubber section collected $25 \cdot 75$ tons of dry Funtumia rubber in Bunyoro and private enterprise 8.04 tons in the Mabira Forest, while in Buganda the Department bought $3 \cdot 13$ tons of vine rubber and private enterprise $2 \cdot 47$ tons. All possible Funtumia trees have been severely tapped twice in two years and are exhausted, so tapping was stopped at the end of the year."

It is to be hoped that all the Departments, now that war-time demands have ceased, will undertake a careful.inventory of their exploited forests, so as to bring to an end any further overfelling where such has occurred.

\section{$22 / 6$ \\ APPOINTMENTS VACANT}

APPLICATIONS are invited for the following appointments on or before the dates mentioned:

LECTURER IN FRUT AND VEgETABLES-The Principal, Midland Agriculturaj Cofege, Sutton Bonington, Loughborough (August 24) ASSISTA I I cetren IN CHEMITRY, preferably with qualification in Parpey ical Chemistry, in the Bradford Technical CollegeTh. $B_{\text {inet }}$ of Education, Town Hall, Bradford (August 24).

LDof ERER IN CHEMISTRY in the Croydon Polytechnic-The Eduction officer, Education Office, Katharine Street, Croydon (August 24).

LECTURERS (2) on MINING SUBJEcts at the Coalville Mining and Technical Institute- The Director of Education, County Offices, Grey Friars, Leicester (August 30).

ENTOMOLOGIST, ASSISTANT LECTURER Or LECTURER IN THE DEPART. MENT OF ZOOLOCY AND COMPARATIVE ANATOMY, and an ASSISTANT LECTURER IN EXPERIMENTAL ZOOLOGY - The Registrar, University College, Cathays Park, Cardiff (August 31).

INSTRUMENT MAKER FOR PHYSICS WORKSHOP-The Head of the Physics and Mathematics Department, Central Technical College, Suffolk Street, Birmingham 1 (August 31).

ASSISTANT LECTURER (man or wOMan) IN BIOLOGY in the Bradford Technical College-The Director of Education, Town Hall, Bradford (August 31). 